\title{
Nutrient Dynamics at the Sediment-Water Interface: Influence of Wastewater Effluents
}

\author{
Meng Zhang $^{1}$ (D) Robert A. Francis ${ }^{1}$ (D) Michael A. Chadwick ${ }^{1}$ (D)
}

Received: 25 June 2021 / Accepted: 1 September 2021 / Published online: 1 October 2021

(c) Springer Nature Switzerland AG 2021

\begin{abstract}
Uptake and regeneration fluxes and concentrations of nutrients, i.e., nitrate $\left(\mathrm{NO}_{3}{ }^{-}\right)$, ammonium $\left(\mathrm{NH}_{4}{ }^{+}\right)$, phosphate $\left(\mathrm{PO}_{4}{ }^{3-}\right)$ and dissolved organic carbon (DOC), were evaluated upstream and downstream of a wastewater treatment plant (WWTP) in the River Wandle, UK, from July to October 2019. Using chamber techniques, water-specific nutrient concentrations were measured at two exposures ( 3 and $10 \mathrm{~min}$ ) to calculate fluxes. The WWTP effluent contributed to elevated concentrations and modified flux rates, resulting in significant differences at the study sites. Compared with summer, the concentrations of $\mathrm{NO}_{3}{ }^{-}$and $\mathrm{DOC}$ increased while $\mathrm{NH}_{4}{ }^{+}$and $\mathrm{PO}_{4}{ }^{3-}$ decreased in autumn. Nutrient fluxes varied both temporally and spatially in uptake (i.e., storage in sediments) or regeneration (i.e., release into river water). Under the actions of physical and biological processes, the fluxes of $\mathrm{NO}_{3}{ }^{-}$and $\mathrm{NH}_{4}{ }^{+}$showed opposite flux directions. Dissolved oxygen (DO) and bioabsorption mainly affected $\mathrm{PO}_{4}{ }^{3-}$ and DOC fluxes, respectively. Specifically, across all sites, $\mathrm{NO}_{3}{ }^{-}$was -0.01 to $+0.02 \mathrm{mg} /\left(\mathrm{m}^{2} \mathrm{~s}\right), \mathrm{NH}_{4}{ }^{+}$was -29 to $+2 \mu \mathrm{g} /\left(\mathrm{m}^{2} \mathrm{~s}\right), \mathrm{PO}_{4}{ }^{3-}$ was -2.0 to $+0.5 \mu \mathrm{g} /\left(\mathrm{m}^{2} \mathrm{~s}\right)$, and DOC was -0.01 to $+0.05 \mathrm{mg} /\left(\mathrm{m}^{2} \mathrm{~s}\right)$. Further, we did find that these variations were related to nutrient concentrations in the overlying water. Our results provide further evidence to show that reductions in river nutrients are paramount for improving river ecological conditions. Additionally, we suggest that more research is needed to evaluate chamberbased experimental approaches to make them more comparable to in-situ flux methods.
\end{abstract}

Highlights

- Sewage effluent resulted in elevated nutrient concentrations and modified fluxes.

- Flux was affected by initial nutrient concentrations, DO and microbial activity.

- Inexpensive approaches to study nutrient dynamics are needed for river restoration.

Keywords Nutrient dynamics · Experimental chambers · Wastewater · Water chemistry · Urban rivers · River Wandle

Michael A. Chadwick

michael.chadwick@kcl.ac.uk

Meng Zhang

meng.zhang@kcl.ac.uk

Robert A. Francis

robert.francis@kcl.ac.uk

1 Department of Geography, King's College London, London, UK 


\section{Introduction}

The "Urban Stream Syndrome" (USS) provides a framework for evaluating responses of watersheds to urbanization (Meyer et al. 2005; Walsh et al. 2005; Booth et al. 2016). USS refers to the degradation of rivers in terms of physical, chemical and biological properties, which can greatly reduce the ecological functions and services of these rivers (Chadwick et al. 2006; Ranta et al. 2021). Pollution associated with urbanization is one focus of USS research (Wenger et al. 2009; Smucker and Detenbeck 2014); improved assessment of pollutant stressors discharged into rivers is needed to provide strategies for improving conditions of these degraded ecosystems (Dalu et al. 2019; Hu et al. 2020). There are a wide range of pollutant stressors to urban rivers (Lele et al. 2018) but nitrogen $(\mathrm{N})$ and phosphorus $(\mathrm{P})$ are among the major threats in most countries of the world (Booth et al. 2016). $\mathrm{N}$ and $\mathrm{P}$ are essential nutrients for aquatic plants and animals to grow and reproduce, but excessive amounts lead to eutrophication (Capps et al. 2016). Dissolved organic carbon (DOC) provides energy for organisms (Mineau et al. 2016); additionally, it is a component of respiratory substrates, thus affecting the uptake of N and P by aquatic organisms (Kirchner et al. 2004; Appling and Heffernan 2014). Therefore, understanding nutrient and DOC dynamics are vital aspects of water quality in urban systems (Rodríguez-Castillo et al. 2019).

Urban areas are the focus of nutrient pollution due to both point and non-point pathways to urban rivers (Wakida and Lerner 2005). For example, urban impervious areas are known to contribute to elevated nutrients in urban rivers (Bedore et al. 2008; Dodds 2006; Li et al. 2020). The loss of vegetation and soils that effectively entrap particulate nutrients can lead to higher loads than if the vegetation and soil were in place. Additionally, the prevention of soil infiltration of soluble nitrogen and phosphorus effectively mobilizes these nutrients to rivers through stormwater runoff (Pfeifer and Bennett 2011). Of course, point sources, such as wastewater treatment plant (WWTP) effluents, significantly increase N, P and DOC concentrations in the receiving water bodies (Preisner 2020). Regardless of the pathways, urban rivers receive pollution which results in nutrient enrichment which impairs environmental quality and affects ecological conditions (Rabalais 2002; Pereda et al. 2020).

Nutrient flux at the water-sediment interface is ecologically important because microbial activity in river sediments is frequently several times greater than in the overlying water column (Wu et al. 2013; Lavelle et al. 2019). Additionally, hydraulic retention and surface area in sediments are much greater (Fellows et al. 2006). Evaluating this ecological function is thus vital for understanding the dynamics of nutrient in streams.

Nitrogen in sediments can be measured in terms of total nitrogen (TN), and $\mathrm{NH}_{4}{ }^{+}$ and $\mathrm{NO}_{3}{ }^{-}$are the greatest components of $\mathrm{TN}$ (Chen and Tang 2005). For $\mathrm{NO}_{3}{ }^{-}$and $\mathrm{NH}_{4}{ }^{+}$, fluxes are primarily controlled by concentration changes and nitrogen form transformation within the $\mathrm{N}$-cycle (Chen et al. 2012). These processes includes denitrification, nitrification, dissimilatory nitrate reduction to ammonium (DNRA), mineralization, and biological nitrogen fixation, which are mainly performed by microorganisms such as nitrifying bacteria, denitrifying bacteria, and mineralized bacteria associated with the decomposition of organic matter (Fear 2003; Mulholland et al. 2008; Meghdadi 2018). Thus, the fluxes of $\mathrm{NO}_{3}{ }^{-}$and $\mathrm{NH}_{4}{ }^{+}$are mainly determined by the microbial activity involved in the N-cycle process (Simon et al. 2010; Lavelle et al. 2019). However, these $\mathrm{N}$-cycle associated transformations are also affected by a range of hydraulic and environmental parameters (see Galloway et al. 2008; Xia et al. 2018). 
Mechanisms of $\mathrm{PO}_{4}{ }^{3-}$-flux at sediment-water interface also involve both biotic and abiotic factors. Phosphate accumulated on urban impervious surfaces enters rivers via surface runoff (Hobbie et al. 2017). Phosphate is used by aquatic plants and microorganisms as nutrients pass along the food chain (Song et al. 2017). However, phosphate is strongly adsorbed by sediments which is a central factor controlling $\mathrm{PO}_{4}{ }^{3-}$-flux at the sediment-water interface. For example, insoluble compounds formed by iron minerals under oxidizing conditions can adsorb phosphate in large amounts (Amirbahman et al. 2003; Luo et al. 2004). Additionally, the surface area of aluminum minerals can provide a large number of adsorption sites for phosphate (Dapeng et al. 2011). When dissolved oxygen (DO) conditions or water $\mathrm{pH}$ changes, insoluble compounds will be converted to soluble, and phosphate can be regenerated into the overlying water. Therefore, phosphate in sediments can be a major source of endogenous phosphorus in aquatic systems, in many cases accounting for a large proportion of total phosphorus (TP). For example, phosphate in sediments of shallow lakes can account for $60-80 \%$ of TP in the whole ecosystem (Penn et al. 1995). Studies have pointed out that long-term river pollution leads to a decrease in the uptake capacity of sediments due to saturation of adsorption sites, which therefore increases the risk of regeneration (Lin et al. 2009; Pereda et al. 2020). This observation is similar to the findings of Earl et al. (2006), who studied the effect of WWTP effluents with high phosphate concentrations and fluxes in receiving rivers. Further, Martí et al. (2010) reported that when biofilms were $\mathrm{P}$ saturated, phosphate was released from sediments, due to the reduced demand for phosphate as a nutrient, resulting in a decreased overall $\mathrm{PO}_{4}{ }^{3-}$-uptake capacity of sediments.

Dissolved organic carbon (DOC) flux is not only dependent on the concentration in sediment and overlying water but also related to $\mathrm{pH}$. Aquatic organisms promote biogenic carbonates synthesis through an alkaline environment as energy supply for biological activities, and its carbon source is DOC, hence the sediment in alkaline water is prone to absorb DOC (Braissant et al. 2007; Santomauro et al. 2012). Furthermore, some studies have found that the organic anions in DOC are competitively adsorbed with phosphate on the adsorption sites of sediment minerals, thus affecting the flux of phosphate (Pant and Reddy 2001; Kuznetsov and Andreeva 2006). Understanding the dynamics of DOC in urban streams and its effects on nutrient flux is an area which need further examination.

Under the actions of microorganisms and/or minerals, nutrients carry on cycling and transformation (e.g., from $\mathrm{NH}_{4}{ }^{+}$to $\mathrm{NO}_{3}{ }^{-}$) in sediments. In addition, some pollutants which are difficult to degrade will directly be adsorbed by sediments, making sediments become a sink of these nutrients (Lavelle et al. 2019; Preisner 2020). When the physicochemical properties of river water change (e.g., seasonal changes in water temperature and DO), or the microbial activities involved in the nutrient dynamics change seasonally, sediments will release nutrients to the overlying water (Smith et al. 2011). Therefore, quantifying the uptake and regeneration of nutrients at the sediment-water interface is essential for understanding overall dynamics of nutrients.

Urban rivers often receive WWTP effluents (Belmeziti et al. 2015) and there are many studies on nutrient concentrations in effluent-affected rivers (e.g., Andersen et al. 2004; Carey and Migliaccio 2009; Gu and Tooker 2016). There are, however, relatively few studies which focus on nutrient fluxes (i.e., uptake and regeneration) at the sediment-water interface. In this study, the River Wandle, an urbanized tributary of the Thames, UK, provides an opportunity to examine nutrient concentrations and fluxes underwater conditions affected by the effluent. We aimed to answer the following questions: (1) How do nutrient dynamics (e.g., concentrations and fluxes of $\mathrm{NO}_{3}{ }^{-}, \mathrm{NH}_{4}{ }^{+}, \mathrm{PO}_{4}{ }^{3-}$ and DOC) in water and sediments vary between sites with and without WWTP discharges? (2) Are there discernable relationships among $\mathrm{NO}_{3}{ }^{-}, \mathrm{NH}_{4}{ }^{+}, \mathrm{PO}_{4}{ }^{3-}$ and DOC concentrations and fluxes at these locations? (3) What are the likley drivers which regulate nutrient concentrations and fluxes? 


\section{Materials and Methods}

\subsection{Study Area}

The River Wandle is a tributary of the River Thames with a channel length of $14 \mathrm{~km}$. The Wandle catchment is located in southwest London with a catchment area of $11 \mathrm{~km}^{2}$ represented by $47 \%$ urban land cover (Smith and Chadwick 2014; Lavelle et al. 2019). The temperature in the river ranges from $\sim 7-22{ }^{\circ} \mathrm{C}$ throughout the year, and the lowest and highest temperatures occur in January and July, respectively. The mean precipitation is 22-45 mm/month, and the minimum and maximum precipitation occur in April and June, respectively (Pike et al. 2014). Located in the catchment is the Beddington WWTP which serves 360,000 people and its outfall discharges into the Wandle (River Wandle Catchment Plan 2014). The effluent standards mainly include ammonium $\left(\mathrm{NH}_{3}-\mathrm{N}\right)$ at $2.5 \mathrm{mg} / \mathrm{L}$, soluble reactive phosphorus (SPR) at $2.6 \mathrm{mg} / \mathrm{L}$, biological oxygen demand (BOD) at $10 \mathrm{mg} / \mathrm{L}$ and solids suspended (SS) at $15 \mathrm{mg} / \mathrm{L}$ (River Wandle Catchment Plan 2014). To evaluate the impact of the WWTP effluent on nutrient concentration and flux, an upstream sampling site not affected by the effluent and two downstream sampling sites affected by the effluent were selected on the River Wandle (Fig. 1). The upstream site with abundant aquatic plants is $0.2 \mathrm{~km}$ above the effluent outfall site (henceforth referred to as U0.2), where the average water depth is $0.25 \mathrm{~m}$ and the average channel width is $8 \mathrm{~m}$; the downstream sites are both associated with residential land and urban green parks. The site $1.0 \mathrm{~km}$ downstream of the effluent outfall is referred to as D1.0 and has an average water depth of $0.35 \mathrm{~m}$ and an average width of $6 \mathrm{~m}$; The site $3.0 \mathrm{~km}$ downstream of the effluent outfall is referred to as D3.0 and has an average water depth of $0.45 \mathrm{~m}$ and an average width of $3 \mathrm{~m}$. The average flow at U0.2 is $\sim 1.7 \mathrm{~m}^{3} / \mathrm{s}$, and the effluent inflow increases the average flow at D1.0 and D3.0 to $\sim 2.7 \mathrm{~m}^{3} / \mathrm{s}$ (River Wandle Catchment Plan 2014). The water temperature is also increased by the effluent; annual mean water temperatures of $11.4{ }^{\circ} \mathrm{C}, 14.0^{\circ} \mathrm{C}$ and $13.4{ }^{\circ} \mathrm{C}$ at U0.2, D1.0, D3.0 were recorded, respectively (River Wandle Catchment Plan 2014). Sediments at all sites were of a mix of gravel, cobble, silt and clay.

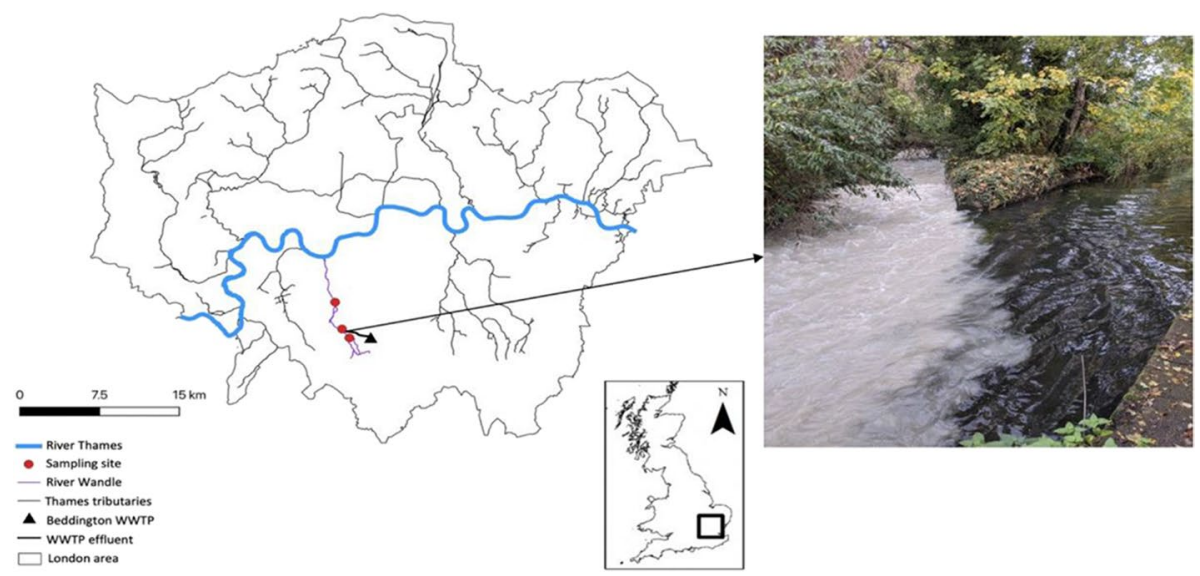

Fig. 1 Sampling sites on the River Wandle, a tributary of the Thames, UK. The sites are U0.2 (upstream of the WWTP), D1.0 (directly downstream of the WWTP) and D3.0 (3 km downstream of the WWTP), respectively. $\mathrm{WWTP}=$ wastewater treatment plant 


\subsection{Sample Collection}

River and sediment samples were collected at each sampling site in 8 days with stable discharge avoiding storm events from July to October 2019. Water samples were taken from different depths at each site, and a composite $500 \mathrm{~mL}$ sample was collected for laboratory testing. Since $\mathrm{NH}_{4}{ }^{+}$is unstable, at each site, another bottle with $400 \mathrm{~mL}$ of working reagent (mixing of sodium sulfite solution, borate buffer solution and ophthalicaldehyde (OPA) solution) was prepared and $100 \mathrm{~mL}$ of river water was added and mixed (see: Holmes et al. 1999). Water $\mathrm{pH}$, water temperature and DO concentration were measured on-site using a multiparameter probe (Hanna HI98194 multiparameter meter). For each site, ten patches $\sim 10 \mathrm{~cm}^{2}$ of the riverbed were randomly selected and $200 \mathrm{~mL}$ of sediments (top $2 \mathrm{~cm}$ ) were collected with a stainless-steel scoop. Water and sediment samples were stored cool separately during transport to the laboratory.

\subsection{Concentration Measurement of $\mathrm{NO}_{3}{ }^{-}, \mathrm{NH}_{4}{ }^{+}, \mathrm{PO}_{4}{ }^{3-}, \mathrm{DOC}$}

$\mathrm{NO}_{3}{ }^{-}$and $\mathrm{PO}_{4}{ }^{3-}$ concentrations were measured by ion chromatography (IC; Dionex Aquion). A series of concentration gradient standards were prepared to periodically calibrate the instrument ( $5 \mathrm{~mL}$ of each standard with sodium nitrate or potassium phosphate). The sample concentrations measured were within the concentration gradient range of prepared standards. The DOC concentration was measured as total organic carbon (TOC) analyzer (SHIMADZU TOC-L). Fluorescence photometry was used to measure $\mathrm{NH}_{4}{ }^{+}$concentration (Holmes et al. 1999; Miró et al. 2003). $\mathrm{NH}_{4}{ }^{+}$methods used are described in detail in Holmes et al. (1999). Before measurements, water samples were filtered through a $0.45 \mu \mathrm{m}$ cellulose membrane in the laboratory.

\subsection{Flux Measurement of $\mathrm{NO}_{3}{ }^{-}, \mathrm{NH}_{4}{ }^{+}, \mathrm{PO}_{4}{ }^{3-}, \mathrm{DOC}$}

Flux experiments were run during baseflow discharge in July and October 2019. In the laboratory, to simulate the interface between water and sediment, the bottom of the $100 \mathrm{~mL}$ chamber (we used opaque chambers for $\mathrm{NH}_{4}{ }^{+}$experiments to reduce photodegradation of the working reagent - Holmes et al. 1999) was evenly covered with $20 \mathrm{~mL}$ of wet surface sediment, and $70 \mathrm{~mL}$ of overlying river water (water containing working reagent for ammonium samples) was then quickly poured onto the sediment. The amount of water and sediment was scaled up by the nitrate flux experiment by Lavelle et al. (2019) in the River Wandle. During the short period after the water was mixed with the sediment, the uptake and regeneration of nutrients were mainly affected by physical disturbance caused by water movement and settlement of sediment particles. About $\mathrm{t}=2.5 \mathrm{~min}$ after mixing, the particle settlement was visualized, and the water was still. During the following period, nutrient fluxes were mainly affected by the microbial action in the sediment under the condition of static water and sediment (Lavelle et al. 2019). In this study, the overlying water was extracted at $\mathrm{t}=0 \mathrm{~min}$ before mixing, and $\mathrm{t}=3 \mathrm{~min}$ and $\mathrm{t}=10 \mathrm{~min}$ after mixing to measure the concentrations of $\mathrm{NO}_{3}{ }^{-}, \mathrm{NH}_{4}{ }^{+}, \mathrm{PO}_{4}{ }^{3-}$, and DOC to represent the process of physical disturbance and biological action (see Lavelle et al. 2019). Considering that the water extraction at $t=3$ min would cause physical disturbance to the system, another experimental set was set up to extract water samples only at $\mathrm{t}=10 \mathrm{~min}$. Both sets had 5 replicates. A DO logger (PME MiniDot oxygen logger) was used to continuously measure the DO concentration in the overlying water during two exposures (0 3 min, 3 10 min). All flux experiments were carried out at the same room temperature. 


\subsection{Sediment Analysis}

We collected an additional $150 \mathrm{~mL}$ of sediment samples at each sampling site, and loss on ignition (Heiri et al. 2001) was used to quantify sediment organic matter content (OM\%). Crucibles were placed in a $120^{\circ} \mathrm{C}$ drying oven for $48 \mathrm{~h}$, then their net weights were weighed $\left(\mathrm{m}_{1}\right)$. The sediments from each sampling site were divided into 3 equal replicates, spread evenly in a tin foil tray, and dried with crucibles for $48 \mathrm{~h}$. After drying and cooling to room temperature, stones and other impurities were filtered out using a $10 \mathrm{~mm}$ pore size sieve, then the sediment was sieved into coarse sediment and fine sediment using a $2 \mathrm{~mm}$ pore size sieve. The coarse and fine sediments were respectively placed in dried crucibles, and the total weight of each was measured. The net weight of the crucible was subtracted from the total weight to obtain the dry weight of the sediment $\left(\mathrm{m}_{2}\right)$. The crucibles containing the sediment were placed in an oven at $550^{\circ} \mathrm{C}$ and burned for $2 \mathrm{~h}$, then placed in a desiccator and cooled to room temperature at which point the weight of each $\left(\mathrm{m}_{3}\right)$ was measured.

The measurement of sediment grain size was carried out across all sites using Malvern Mastersizer 2000 granulometer. The other half of the fine sediment in the OM\% measurement was used for the average grain size analysis. This procedure was repeated three times for each site. Samples were classified as either sand $(0.063-2 \mathrm{~mm})$, silt $(0.004-0.063 \mathrm{~mm})$, or clay $(<0.004 \mathrm{~mm})$ (Lee et al. 2010).

\subsection{Data Analysis}

For the measurement of $\mathrm{NH}_{4}{ }^{+}$concentration, the matrix effect was derived from the following formula:

$$
M E=\frac{\left(F_{\text {std spike }}-F_{\text {std zero }}\right)-\left(F_{\text {sample spike }}-F_{\text {sample obs }}\right)}{\left(F_{\text {std spike }}-F_{\text {std zero }}\right)} \times 100 \%
$$

where $\mathrm{F}_{\text {stdzero }}$ is the fluorescence of the blank; $\mathrm{F}_{\text {stdspike }}$ and $\mathrm{F}_{\text {sample spike }}$ are the fluorescence of the blank and the sample after adding $1 \mathrm{~mL}$ of $1 \mu \mathrm{g} / \mathrm{L}$ ammonium stock solution; $\mathrm{F}_{\text {sample obs }}$ is the measured sample fluorescence.

The $\mathrm{NH}_{4}{ }^{+}$fluorescence was obtained after subtracting the background fluorescence:

$$
F_{N_{4}^{+}}=F_{\text {sample obs }}-F_{B F}
$$

The final $\mathrm{NH}_{4}{ }^{+}$fluorescence was derived from the following formula:

$$
F_{\text {sample }}=F_{\mathrm{NH}_{4}^{+}}+F_{\mathrm{NH}_{4}^{+}}\left(\frac{\mathrm{ME}}{100}\right)
$$

$\mathrm{NO}_{3}{ }^{-}, \mathrm{NH}_{4}{ }^{+}, \mathrm{PO}_{4}{ }^{3-}$ and DOC fluxes were derived from the following formula:

$$
f=\frac{\left(C_{2}-C_{1}\right) V}{A\left(t_{2}-t_{1}\right)}
$$

where $C_{1}$ and $C_{2}$ refer to the nutrient concentration at times $t_{1}$ and $t_{2}$, respectively; $V$ is the volume of the overlying water $(\mathrm{L})$; $\mathrm{A}$ is the surface area of the sediment surface $\left(\mathrm{m}^{2}\right) ; \mathrm{t}_{2}-\mathrm{t}_{1}$ is the time (s) between the subsequent $\left(\mathrm{t}_{2}\right)$ and previous $\left(\mathrm{t}_{1}\right)$ water extraction. $\mathrm{NO}_{3}{ }^{-}$and DOC fluxes are expressed as $\mathrm{mg} /\left(\mathrm{m}^{2} \mathrm{~s}\right) ; \mathrm{NH}_{4}{ }^{+}$and $\mathrm{PO}_{4}{ }^{3-}$ fluxes are expressed as $\mu \mathrm{g} /\left(\mathrm{m}^{2}\right.$ 
s). A positive flux indicates the movement of nutrients from the sediment to the overlying water and a negative flux indicates the movement of nutrients from the overlying water to the sediment.

The sediment organic content was derived from the following formula:

$$
O M \%=\frac{m_{1}-m_{3}}{m_{2}} \times 100 \%
$$

where $\mathrm{m}_{1}$ is crucible net weight; $\mathrm{m}_{2}$ is sediment dry weight; $\mathrm{m}_{3}$ is crucible weight after burning in the oven.

\subsection{Data Analysis}

We sought to evaluate differences both among our three study sites and between the twotime exposures in the experiments. To accomplish this, we used two-way analysis of variance for each measured water chemistry variable and parameter-specific flux estimates. Due to our relatively small sample sizes, we used non-parametric tests (i.e., Kruskal Wallis). Additionally, to explore overall relationships among water chemistry and flux values, we examined correlations (i.e., Spearman) across these parameters. All statistics were performed in SPSS 18.0 or R language 3.5.2.

\section{Results}

\subsection{River Wandle Water Quality}

Nitrate and Ammonium: There were significant differences in $\mathrm{NO}_{3}{ }^{-}$and $\mathrm{NH}_{4}{ }^{+}$concentrations among sampling sites $(F=29.446, p<0.001 ; F=106.97, p<0.001$, respectively), both concentrations were highest at D1.0 and lowest at U0.2 (Fig. 2). $\mathrm{NO}_{3}{ }^{-}$ranged from $\sim 4$ to $17 \mathrm{mg} / \mathrm{L}$ and $\mathrm{NH}_{4}{ }^{+}$ranged from $\sim 0.07$ to $1.95 \mathrm{mg} / \mathrm{L}$ (Fig. 2a). No significant correlation was observed between the concentrations of $\mathrm{NO}_{3}{ }^{-}$and $\mathrm{DO}\left(r^{2}=-0.344, p>0.05\right)$, while $\mathrm{NH}_{4}{ }^{+}$concentration was positively correlated with water temperature $\left(r^{2}=0.738\right.$, $p<0.001$; Table 1). Compared with July and August, in September and October, the $\mathrm{NO}_{3}{ }^{-}$ concentration moderately increased at U0.2 and D3.0 ( $p=0.073, p=0.885$, respectively), and with a significant increase at D1.0 $(p=0.037)$. Similarly, the $\mathrm{NH}_{4}{ }^{+}$concentration moderately decreased at U0.2 and D3.0 ( $p=0.070, p=0.738$, respectively), and with a significant decrease at D1.0 ( $p=0.034)$ (Fig. 2b).

Phosphate ${ }^{-}$: The $\mathrm{PO}_{4}{ }^{3-}$ concentration was highest at D1.0 and lowest at U0.2, ranging from $\sim 0.3$ to $1.2 \mathrm{mg} / \mathrm{L}$ (Fig. 2a). There was a significant difference in the $\mathrm{PO}_{4}{ }^{3-}$ concentration between U0.2 and D1.0 $(p=0.001)$, and U0.2 and D3.0 $(p=0.001)$, while no significant difference was observed between D1.0 and D3.0 $(p=0.597)$. The $\mathrm{PO}_{4}{ }^{3-}$ concentration was negatively correlated with DO, and it decreased at D1.0 and D3.0 in September and October ( $p=0.016, p=0.126$, respectively), but increased by $5 \%$ at U0.2 $(p=0.845)$ (Fig. 2b).

Dissolved organic carbon: The DOC concentration was highest at D1.0 and lowest at U0.2, ranging from $\sim 1.6$ to $5.5 \mathrm{mg} / \mathrm{L}$ (Fig. 2a), and it was significantly different among sampling sites $(F=93.999, p<0.001)$. In September and October, DOC increased by $3.5 \%(p=0.295), 2.8 \%(p=0.794)$, and $5.6 \%(p=0.359)$ at U0.2, D1.0, D3.0, respectively 
Fig. 2 a Concentrations of nutrients $\left(\mathrm{NO}_{3}{ }^{-}, \mathrm{NH}_{4}{ }^{+}, \mathrm{PO}_{4}{ }^{3-}\right.$, DOC) and DO and water temperature at the three sampling sites. Each box contains eight corresponding datapoints from eight sampling events from July to October. The concentrations of these four nutrients were the highest at D1.0 and the lowest at U0.2. The concentrations of $\mathrm{NO}_{3}{ }^{-}, \mathrm{NH}_{4}{ }^{+}$and DOC were significantly different among all sampling sites, while $\mathrm{PO}_{4}{ }^{3-}$ concentrations were only significantly different between U0.2 and D1.0 or between U0.2 and D3.0. Fig. 2b Concentrations of nutrients $\left(\mathrm{NO}_{3}{ }^{-}, \mathrm{NH}_{4}{ }^{+}, \mathrm{PO}_{4}{ }^{3-}\right.$, DOC) and DO and water temperature at the three sampling sites from July to October. The circle represents U0.2, the triangle represents D3.0, and the square represents D1.0. Compared with July and August, in September and October, $\mathrm{NO}_{3}{ }^{-}$and $\mathrm{NH}_{4}{ }^{+}$concentrations increased and decreased significantly at D1.0; $\mathrm{PO}_{4}{ }^{3-}$ concentrations decreased significantly at D1.0; There were no significant variations in DOC concentrations among all sites

(Fig. 2b). Across all sites, positive correlations were observed between DOC and other nutrient concentrations (Table 1).

\subsection{Sediment Analysis}

Sediments used for the flux experiments varied both among and between sites. Generally, fine sediments (particle size $<2 \mathrm{~mm}$ ) contained more organic matter than coarse sediments (particle size $>2 \mathrm{~mm}$ ). Sediments of all sampling sites were mainly composed of silt, with the highest proportion of fine sediment at U0.2 and the highest proportion of coarse sediment at D1.0 (Table 2).

\subsection{DO, $\mathrm{NO}_{3}{ }^{-}, \mathrm{NH}_{4}{ }^{+}, \mathrm{PO}_{4}{ }^{3-}$ and DOC Fluxes at the Sediment-Water Interface}

Nitrate and ammonium: Across all sites, $\mathrm{NO}_{3}{ }^{-}$fluxes in both exposure periods ranged from -0.01 to $+0.02 \mathrm{mg} /\left(\mathrm{m}^{2} \mathrm{~s}\right)$ and $\mathrm{NH}_{4}{ }^{+}$ranged from -29 to $+2 \mu \mathrm{g} /\left(\mathrm{m}^{2} \mathrm{~s}\right)$ (Fig. 3a, 4b). There was no significant difference in $\mathrm{NO}_{3}{ }^{-}(p=0.577)$ and $\mathrm{NH}_{4}{ }^{+}(p=0.636)$ fluxes between July and October. $\mathrm{NO}_{3}{ }^{-}$and $\mathrm{NH}_{4}{ }^{+}$fluxes showed the opposite direction at one sampling site, except in the case of U0.2 in October, where both regeneration and uptake occurred. Both nitrate and ammonium fluxes were slower during the 3-10 min experiment when compared to the $0-3$ min experiment.

Phosphate: $\mathrm{PO}_{4}{ }^{3-}$ fluxes in both exposure periods ranged from -2.0 to $+0.5 \mu \mathrm{g} /$ $\left(\mathrm{m}^{2} \mathrm{~s}\right)$ and varied significantly between the two seasons $(p=0.008$; Fig. $3 \mathrm{c}) . \mathrm{PO}_{4}{ }^{3-}$ was absorbed by the sediment among all sites in summer sampling events, while it was regenerated in autumn. $\mathrm{PO}_{4}{ }^{3-}$ fluxes decreased with exposure period, the decrease in regeneration fluxes $\left(0.077,0.072,0.077 \mu \mathrm{g} /\left(\mathrm{m}^{2} \mathrm{~s}\right)\right.$ for U0.2, D1.0, D3.0, respectively) was lower than the decrease in uptake fluxes $\left(0.419,0.413,0.18 \mu \mathrm{g} /\left(\mathrm{m}^{2} \mathrm{~s}\right)\right.$ for U0.2, D1.0, D3.0, respectively).

Dissolved organic carbon: DOC showed uptake fluxes in both seasons at D3.0 and was regenerated in both exposure periods in autumn sampling events at other sites. DOC fluxes ranged from -0.01 to $+0.05 \mathrm{mg} /\left(\mathrm{m}^{2} \mathrm{~s}\right)$ and no significant difference was observed between the two seasons ( $p=0.902$; Fig. $3 d)$.

DO flux: There was a positive correlation between the DO consumption flux and the regeneration fluxes of $\mathrm{NH}_{4}{ }^{+}$and $\mathrm{PO}_{4}{ }^{3-}$, while no correlation was observed between the DO consumption flux and $\mathrm{NO}_{3}{ }^{-}$or DOC regeneration flux (Table 3). Only the initial $\mathrm{PO}_{4}{ }^{3-}$ concentration was negatively correlated with $\mathrm{PO}_{4}{ }^{3-}$ regeneration flux (Table 3). This indicates that in the overlying water, DO conditions and initial nutrient concentrations cannot completely independently affect nutrient fluxes. 
a
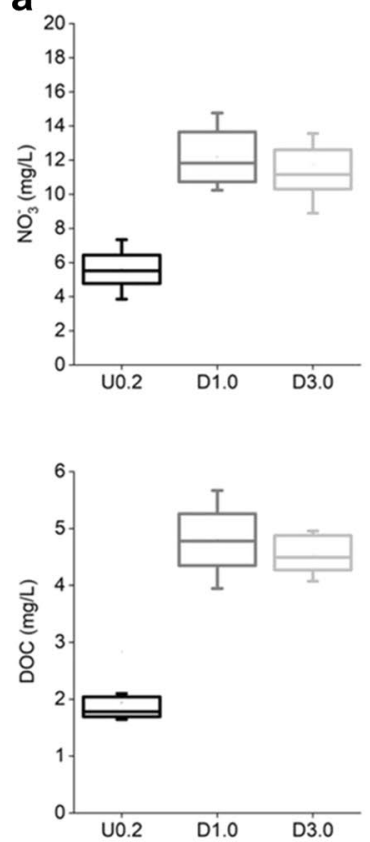

b
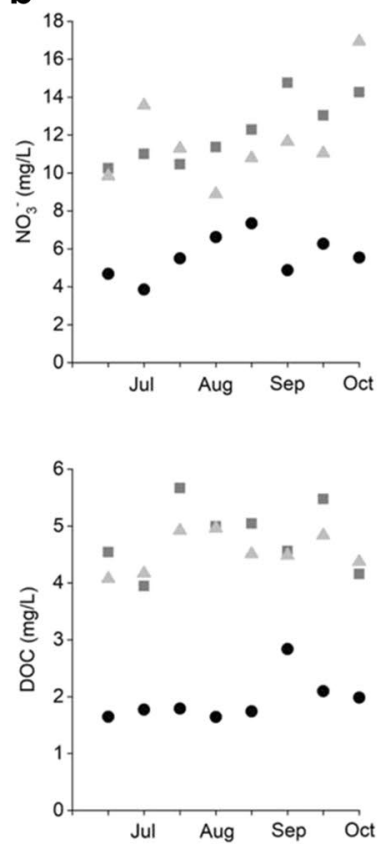
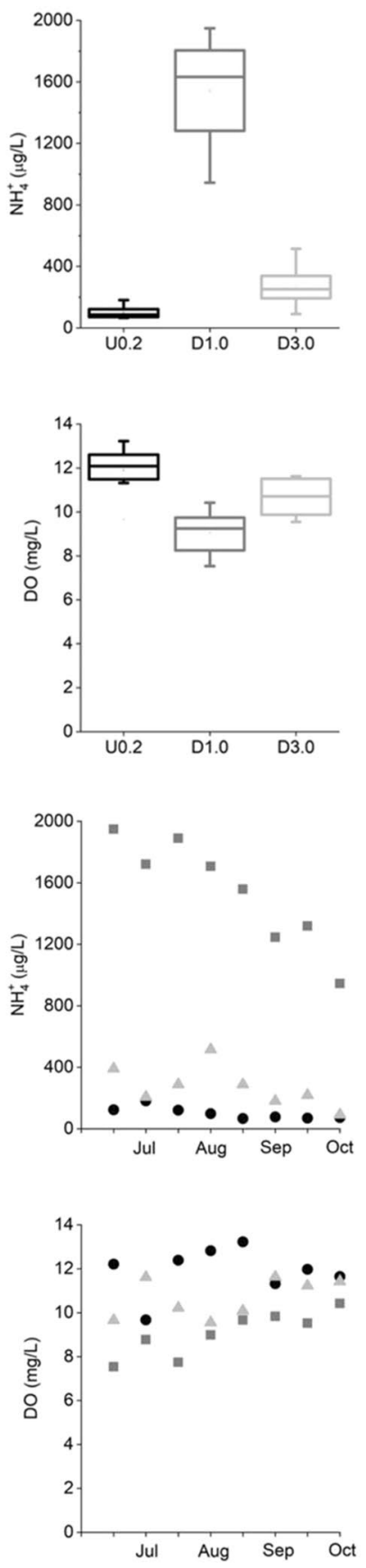
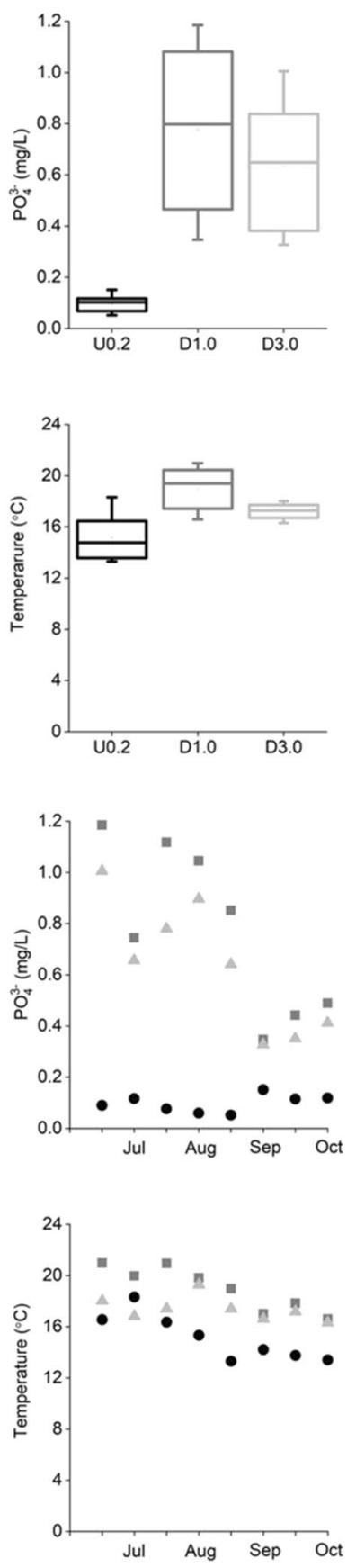
Table 1 Correlation matrix of River Wandle water quality parameters over the entire experimental period

\begin{tabular}{|c|c|c|c|c|c|}
\hline & $\mathrm{NO}_{3}^{-}$ & $\mathrm{NH}_{4}^{+}$ & $\mathrm{PO}_{4}{ }^{3-}$ & DOC & DO \\
\hline $\mathrm{NH}_{4}$ & $\mathrm{r}^{2}=0.421^{*}$ & & & & \\
\hline $\mathrm{PO}_{4}{ }^{3}$ & $\mathrm{r}^{2}=0.481 *$ & $\mathrm{r}^{2}=0.711 * * *$ & & & \\
\hline DOC & $\mathrm{r}^{2}=0.782 * * *$ & $\mathrm{r}^{2}=0.641 * * *$ & $\mathrm{r}^{2}=0.780^{* * *}$ & & \\
\hline DO & $r^{2}=-0.344$ & $\mathrm{r}^{2}=-0.807 * * *$ & $\mathrm{r}^{2}=-0.832 * * *$ & $\mathrm{r}^{2}=-0.694 * * *$ & \\
\hline temp & $r^{2}=0.353$ & $r^{2}=0.738 * * *$ & $\mathrm{r}^{2}=0.829 * * *$ & $r^{2}=0.668 * * *$ & $\mathrm{r}^{2}=-0.880 * * *$ \\
\hline
\end{tabular}

Note: The overall sample size was 24 . " $\mathrm{r}$ " is the Spearman correlation coefficient. "*" indicates a significant correlation of $\mathrm{p}<0.05$; “**" indicates a significant correlation of $\mathrm{p}<0.01$; “***" indicates a significant correlation of $\mathrm{p}<0.001$

\section{Discussion}

Research to quantify the nutrient dynamics in urban river ecosystems helps to improve river restoration practices and provide needed evidence to support conservation policies geared towards returning rivers to improved ecological conditions. In our study we explored the dynamics of $\mathrm{NO}_{3}{ }^{-}, \mathrm{NH}_{4}{ }^{+}, \mathrm{PO}_{4}{ }^{3-}$, and DOC at the sediment-water interface in an urban river ecosystem (River Wandle) affected by a WWTP outfall. Our results indicated that the discharged WWTP effluent to the sampling site D1.0 contributed the highest nutrient concentrations and the lowest DO concentration (Fig. 2). Compared with the other sites, the sediment at D1.0 was the largest source of $\mathrm{NO}_{3}{ }^{-}$and DOC and the largest sink of $\mathrm{NH}_{4}{ }^{+}$in July and October (Fig. 4). Specifically, flux at the sediment-water interface was affected by initial nutrient concentrations, DO conditions in the overlying water and likely patch-scale microbial activity in the sediment affecting nutrient dynamics.

The rate and direction of nutrient flux (i.e., uptake and regeneration) were likely determined by the nutrient concentration in water and sediment, and the concentration changes between the two media are influenced by a combination of physical processes (e.g., water advection) and biogeochemical processes. Generally, the role of sediments as $\mathrm{NO}_{3}{ }^{-}$producers/consumers is accompanied by the role as $\mathrm{NH}_{4}{ }^{+}$consumers/producers (Fig. 3), which is related to nitrification, dissimilatory nitrate reduction to ammonium (DNRA) process in the $\mathrm{N}$-cycle, respectively, which are affected by their concentrations, seasonal water temperature and DO (Helton et al. 2011; Reisinger et al. 2016). For $\mathrm{PO}_{4}{ }^{3-}$ flux, insoluble or

Table 2 Sediment condition summary. Category refers to the proportion of fine and coarse sediments in the sample (in brackets); OM\%= percentage of organic matter, numbers in followed brackets are standard deviation; Composition refers to the proportion of particle size in the fine sediment. Each sediment sample was measured in three replicates

\begin{tabular}{lllll}
\hline Site & Category & Mean OM\% & Composition & \\
\hline U0.2 & Fine sediment $(43.6 \%)$ & $15.398(0.39)$ & Sand 0.0\% & Clay 5.2\% \\
& Coarse sediment $(56.4 \%)$ & $4.234(0.20)$ & Silt $94.8 \%$ & \\
D1.0 & Fine sediment $(26.8 \%)$ & $29.710(1.08)$ & Sand 0.0\% & Clay 2.2\% \\
& Coarse sediment $(73.2 \%)$ & $8.320(0.04)$ & Silt 97.8\% & Clay 1.8\% \\
D3.0 & Fine sediment $(37.7 \%)$ & $13.625(0.69)$ & Sand 0.0\% & \\
& Coarse sediment $(62.3 \%)$ & $3.252(0.17)$ & Silt $98.2 \%$ & \\
\hline
\end{tabular}




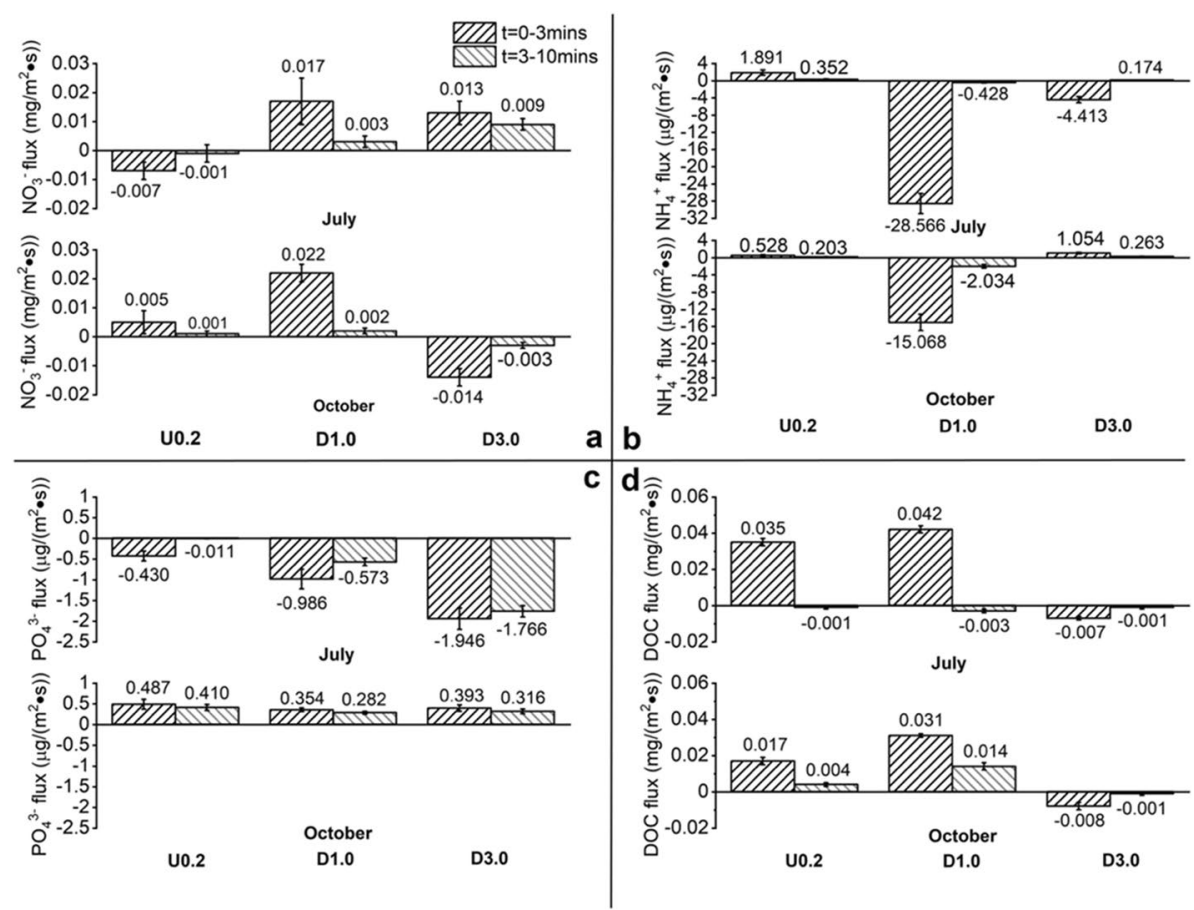

Fig. $3 \mathrm{NO}_{3}{ }^{-}$(a), $\mathrm{NH}_{4}{ }^{+}$(b), $\mathrm{PO}_{4}{ }^{3-}$ (c) and DOC (d) fluxes for both periods during July and October sampling events. $\mathrm{NO}_{3}{ }^{-}$and DOC fluxes are in $\mathrm{mg} /\left(\mathrm{m}^{2} \mathrm{~s}\right) ; \mathrm{NH}_{4}{ }^{+}$and $\mathrm{PO}_{4}{ }^{3-}$ fluxes are in $\mu \mathrm{g} /\left(\mathrm{m}^{2} \mathrm{~s}\right)$. Downwards flux represents uptake/removal of nutrients from the overlying water to the sediment and upwards flux represents regeneration/release of nutrients from the sediment to the water. The number above bars is the mean of nutrient flux among replicates, and error lines are marked on the bars. In each experiment season, we set up five replicates, each containing $20 \mathrm{~mL}$ of sediment and $70 \mathrm{~mL}$ of overlying river water. Only phosphate fluxes showed significant seasonal differences

Fig. 4 DO consumption for both periods during July and October sampling events. The number above bars is the mean of the DO consumption flux, and error lines are marked on the bars. The data came from the miniDot logger, which was able to continuously measure DO in the two exposures. We used the difference in DO concentration between the beginning and the end time to estimate DO consumption
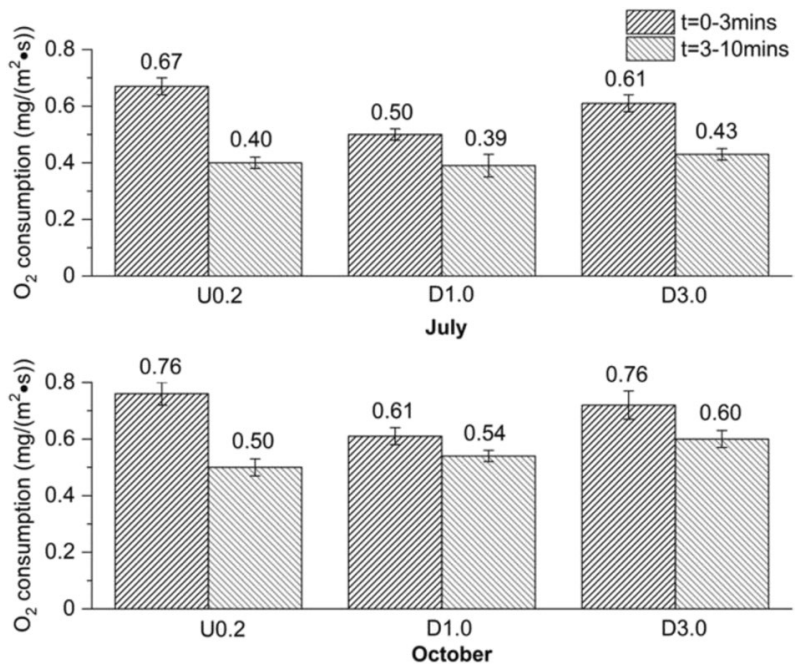
Table 3 Correlation matrix between nutrient flux and DO consumption flux in the overlying water and initial nutrient concentration $(\mathrm{t}=0 \mathrm{~min})$

\begin{tabular}{lllll}
\hline & $\mathrm{NO}_{3}{ }^{-}$flux & $\mathrm{NH}_{4}{ }^{+}$flux & $\mathrm{PO}_{4}{ }^{3-}$ flux & DOC flux \\
\hline DO consumption & $\mathrm{r}=0.192 \mathrm{~N} / \mathrm{A}$ & $\mathrm{r}=0.556 *$ & $\mathrm{r}=0.601 *$ & $\mathrm{r}=0.069 \mathrm{~N} / \mathrm{A}$ \\
Initial $\mathrm{NO}_{3}{ }^{-}$concentration & $\mathrm{r}=0.410 \mathrm{~N} / \mathrm{A}$ & & & \\
Initial $\mathrm{NH}_{4}{ }^{+}$concentration & & $\mathrm{r}=0.286 \mathrm{~N} / \mathrm{A}$ & & $\mathrm{r}=0.075 \mathrm{~N} / \mathrm{A}$ \\
$\begin{array}{l}\text { Initial } \mathrm{PO}_{4}{ }^{-} \text {concentration } \\
\text { Initial DOC concentration }\end{array}$ & & & $\mathrm{r}=-0.850 * *$ & \\
\hline
\end{tabular}

The sample size is 12. " $\mathrm{r}$ " is Spearman correlation coefficient (positive values represent regeneration flux; negative values represent uptake flux). "*” indicates a significant difference of $\mathrm{p}<0.05$; “**” indicates a significant difference of $\mathrm{p}<0.01$; "N/A" indicates no significant difference

soluble matter in sediment particles affected by DO can interact with minerals and change adsorption sites and adsorption capacity of sediments likely responsible for our observed differences (Bedore et al. 2008; Wu et al. 2018); Additionally, $\mathrm{PO}_{4}{ }^{3-}$ flux relates to the zero equilibrium phosphorus concentration (EPC0). When the $\mathrm{PO}_{4}{ }^{3-}$ concentration in the water column deviates from EPC0, the migration of $\mathrm{PO}_{4}{ }^{3-}$ will increase (McDowell 2015). DOC dynamics, related to its roles as a biological energy source, can be affected by ecosystem metabolism and the content of organic matter in sediments (Kaushal et al. 2014; Zhang and Chadwick, in review).

\subsection{Mechanisms Driving $\mathrm{NO}_{3}{ }^{-}$and $\mathrm{NH}_{4}{ }^{+}$Concentrations and Fluxes}

After water and sediment samples were mixed, the mutual disturbance of the two media caused $\mathrm{NH}_{4}{ }^{+}$to migrate along the concentration gradient. Specifically, in the summer experiments (i.e., July), we observed that D1.0 with the highest $\mathrm{NH}_{4}{ }^{+}$concentration in the overlying water was accompanied by the highest $\mathrm{NH}_{4}{ }^{+}$uptake rate during the $0-3$ min and 3-10 min exposures, followed by D3.0, while U0.2 with the lowest $\mathrm{NH}_{4}{ }^{+}$concentration released $\mathrm{NH}_{4}^{+}$with a regeneration rate similar to that reported by Lavelle et al. (2019) (Fig. 3b). In terms of biological processes, the movement of water transferred $\mathrm{NO}_{3}{ }^{-}$into the sediment and likely made it bioavailable with microbes associated within sediment surfaces. The DO consumption during both exposures favored the occurrence of the DNRA reaction, so that $\mathrm{NO}_{3}{ }^{-}$was transformed into $\mathrm{NH}_{4}{ }^{+}$and returned to the overlying water with the water flow or along the concentration gradient (Altmann et al. 2003). This is consistent with the opposite flux direction of $\mathrm{NO}_{3}{ }^{-}$and $\mathrm{NH}_{4}{ }^{+}$observed across all sites (Fig. 3a). Additionally, we found that the $\mathrm{NH}_{4}{ }^{+}$flux rate decreased with decreased $\mathrm{NH}_{4}{ }^{+}$concentration in the overlying water, which occurred not only at each site but also in the later exposure (3-10 min). This was because $\mathrm{NH}_{4}{ }^{+}$generated by microbial transformation gradually decreased with decreased $\mathrm{NO}_{3}{ }^{-}$entering the sediment. Under the action of physical and biological processes, the decreased $\mathrm{NH}_{4}{ }^{+}$concentration difference between water and sediment resulted in a decreased flux rate.

Among our study sites concentrations of $\mathrm{NO}_{3}{ }^{-}$and $\mathrm{NH}_{4}^{+}$were significantly different among river reaches $(F=106.97, p<0.001)$ with D1.0 having the highest nutrient concentrations. The effluent with elevated water temperatures and the highest content of organic matter (Table 2) promoted the mineralization of organic nitrogen by microbes likely supporting the highest $\mathrm{NH}_{4}{ }^{+}$concentration reaching $>1 \mathrm{mg} / \mathrm{L}$ and the acceleration 
of $\mathrm{NH}_{4}{ }^{+}$uptake (Souza et al. 2011). Further, we observed significant positive correlations between water temperature and $\mathrm{NH}_{4}{ }^{+}$concentration $\left(r^{2}=0.738, p<0.001\right), \mathrm{NO}_{3}{ }^{-}$and DO $\left(r^{2}=0.818, p<0.001\right)$. The correlation of $\mathrm{NH}_{4}{ }^{+}$was consistent with the findings of Cole et al. (2002) who found that elevated temperatures promoted biological activity, and thus, enhanced mineralization, and the correlation $\mathrm{NO}_{3}{ }^{-}$was attributed to nitrification (Fear 2003; Yang et al. 2012).

$\mathrm{NO}_{3}{ }^{-}$and $\mathrm{NH}_{4}{ }^{+}$concentrations decreased at D3.0 compared with D1.0. As nutrients were transported from the midriver reach, and the conversion to $\mathrm{N}_{2}$ gas (i.e., nitrifier denitrification) or other forms of nitrogen (e.g., associated with biological storage) was likely achieved (Fear 2003; Mulholland et al. 2008; Meghdadi 2018). D3.0 concentrations of $\mathrm{NO}_{3}{ }^{-}$were higher than the upstream reach, which was consistent with the findings of Perryman et al. (2011) who pointed out that $\mathrm{NO}_{3}{ }^{-}$increased downstream with increasing river discharge due to short water residence time. However, at D3.0, $\mathrm{NH}_{4}{ }^{+}$re-entered the overlying water in the 3-10 min exposure, which was likely because the overlying water could not provide sufficient $\mathrm{NH}_{4}{ }^{+}$as $\mathrm{NH}_{4}{ }^{+}$continued to enter the sediment, and the nitrification was inhibited, resulting in decreased $\mathrm{NO}_{3}{ }^{-}$regeneration flux and conversion of $\mathrm{NH}_{4}{ }^{+}$from uptake to regeneration flux. These spatial variations across our study sites can be attributed to changes in overall nutrient spiralling dynamics and variations in nutrient supply associated with the WWTP effluents (Grimm et al. 2005; Haggard et al. 2005; Ensign and Doyle 2006).

In autumn experiments (i.e., October), the concentration of $\mathrm{NH}_{4}{ }^{+}$and river water temperature decreased, while an increase in the $\mathrm{NO}_{3}{ }^{-}$concentration was observed. The increased seasonal precipitation in southeast England and the River Wandle catchment is likely an important factor for the increased $\mathrm{NO}_{3}{ }^{-}$concentration because surface runoff as a non-point source of pollution carried $\mathrm{NO}_{3}{ }^{-}$from urban impervious surfaces into the river (Ko et al. 2010). Although increased precipitation and runoff can also dilute $\mathrm{NO}_{3}{ }^{-}$concentrations, pollution associated with surface runoff can be significantly stronger than dilution (Monfared et al. 2017) and this needs further attention for the River Wandle. Regardless, we found decreased $\mathrm{NH}_{4}{ }^{+}$fluxes accompanied by reduced $\mathrm{NH}_{4}{ }^{+}$concentrations in October. However, for $\mathrm{NO}_{3}{ }^{-}$flux, increased concentrations resulted in an uptake flux of $\mathrm{NO}_{3}{ }^{-}$at D3.0, which was the opposite of the case in July.

\subsection{Mechanisms Driving $\mathrm{PO}_{4}{ }^{3-}$ Concentrations and Fluxes}

The River Wandle catchment management plan (Pike et al. 2014) identified exogenous sources of $\mathrm{PO}_{4}{ }^{3-}$ in the river from WWTP effluents, detergents and oil accumulated on urban impervious surfaces and animal waste. In our study, the highest $\mathrm{PO}_{4}{ }^{3-}$ concentration at D1.0 was owing to the effects of the WWTP effluents; however, the contribution from $\mathrm{PO}_{4}{ }^{3-}$ released from the sediment was less, which was reflected in the lowest $\mathrm{PO}_{4}{ }^{3-}$ regeneration rate at this site in October (Fig. 3c). This was because the high content of organic matter at D1.0 can form biofilms on the sediment surface and reduce the interaction between $\mathrm{PO}_{4}{ }^{3-}$ and sediment (e.g., adsorption site), thereby reducing the regeneration/ uptake of $\mathrm{PO}_{4}{ }^{3-}$ from/to the sediment as we observed in both seasons (Pant and Reddy 2001; Kuznetsov and Andreeva 2006).

We observed that $\mathrm{PO}_{4}{ }^{3-}$ concentrations were negatively correlated with DO $\left(r^{2}=-0.832, p<0.001\right)$ and positively correlated with water temperature $\left(r^{2}=0.829\right.$, $p<0.001$ ). DO conditions affect electron receptors in sediments (e.g., $\mathrm{Fe}^{3+}$ ), thereby affecting the formation of soluble and insoluble substances more than the adsorption of $\mathrm{PO}_{4}{ }^{3-}$ (House and Denison 2000). For example, under reducing conditions, the form of $\mathrm{Fe}(\mathrm{OH})_{2}$ 
reduces the adsorption sites for $\mathrm{PO}_{4}{ }^{3-}$; Under oxidizing conditions, the conversion of $\mathrm{Fe}^{2+}$ to $\mathrm{Fe}^{3+}$ is very slow. Once a large amount of insoluble matter is formed, the $\mathrm{PO}_{4}{ }^{3-}$ uptake by sediments is weakened, resulting in increased $\mathrm{PO}_{4}{ }^{3-}$ concentrations in the overlying water (Zhao et al. 2015; Martí et al. 2021). For the effect of water temperature, Jin et al. (2008) and Wang et al. (2009) found that increased water temperature can promote the generation of phosphatase by aquatic organisms and lead to the production of more soluble phosphorus (e.g., $\mathrm{PO}_{4}{ }^{3-}$ ). In our study, we suspect the effect of lower water temperature, slowed metabolism and increased DO in autumn led to a decrease in $\mathrm{PO}_{4}{ }^{3-}$ concentrations.

Sediments at U0.2 contained the highest proportion of fine particles (Table 2), which were easy to resuspend due to the slow sedimentation speed, causing $\mathrm{PO}_{4}{ }^{3-}$ to re-enter the overlying water (Luo et al. 2004). This could explain that U0.2 had the lowest $\mathrm{PO}_{4}{ }^{3-}$ uptake flux in July and the highest regeneration flux in October.

There was a significant positive correlation between $\mathrm{PO}_{4}{ }^{3-}$ and water $\mathrm{pH}\left(r^{2}=0.636\right.$, $p=0.001)$. The river reaches at all sites were alkaline $(\mathrm{pH}=7.7 \sim 8.9)$, causing $\mathrm{OH}^{-}$and $\mathrm{PO}_{4}{ }^{3-}$ to compete for adsorption sites on the sediment surface and exchange with $\mathrm{PO}_{4}{ }^{3-}$, consequently increasing the $\mathrm{PO}_{4}{ }^{3-}$ concentration in the water, which is regarded as the mechanism by rivers to regulate $\mathrm{PO}_{4}{ }^{3-}$ levels (Jin et al. 2008).

\subsection{Mechanisms Driving DOC Concentrations and Fluxes}

In July, the samples at U0.2 and D1.0 with high DOC content released DOC into the overlying water during 0-3 min exposure (Fig. 3d). However, during 3-10 min exposure, sediments among all sites absorbed DOC, which was likely due to the fact that microorganisms increase the saturation index of biogenic carbonate minerals through their metabolic activities, and DOC is a carbon source (Braissant et al. 2007; Santomauro et al. 2012). The fine sediments across all sites were mainly composed of silt, and clay accounted for a small fraction (Table 2). Such sediment textures have a high surface area available for microbial adhesion and colonization, resulting in high microbial biomass and diversity (Sessitsch et al. 2001; Fear 2003). Therefore, the sampling sites may have similar microbial biomass and diversity, resulting in no difference in the DOC uptake flux among all sites in July. Such biological effects were weakened in October, causing regeneration fluxes of DOC at U0.2 and D1.0 during 3-10 min exposure.

In October, the DOC concentration increased across all sites, which was due to the fact that DOC accumulating in riparian areas and urban impervious surfaces likely entered the river with increased stormwater runoff (Correll et al. 2001); Additionally, leaves falling into the river is another main carbon source (Kalbitz et al. 2000). The content of organic matter in sediments varies little with seasons (Hook and Yeakley 2005). For U0.2 and D1.0 samples, the increased DOC concentration in the overlying water caused decreased regeneration fluxes during 0-3 min exposure compared with the same exposure of July. However, in these two seasons, DOC uptake fluxes were measured at D3.0 and the flux rates were almost unchanged, which likely attributed to the increased downstream flow with a dilution effect on the increased DOC concentration in autumn (Worrall et al. 2003).

\subsection{Flux Predicted by Nutrient Concentrations and Water Temperature}

In our flux experiment, we did not look for interactions across nutrient dynamics. However, using values from our flux measurements and comparing these against ambient river water 
quality could provide some additional insight into our observed flux patterns. To investigate this further, we used simple forward selection stepwise multiple regression to evaluate if all of our measured flux rates could be predicted from ambient river water quality. This is a heuristic, exploratory approach because we did not measure changes in all water quality parameters which would relate directly to an individual, chamber-specific flux measurement. Overall, we found significant models for all of our flux measurements (Table 4). For $\mathrm{NO}_{3}{ }^{-}$flux, only $\mathrm{NH}_{4}{ }^{+}$concentration explained overall differences. This suggests that nitrification likely plays a strong role in our study which is similar to results from other WWTP affected rivers (Jiao et al. 2009; Merbt et al. 2015). For $\mathrm{PO}_{4}{ }^{3-}$ flux, only $\mathrm{PO}_{4}{ }^{3-}$ concentration explained overall differences, but this was a negative relationship which suggests that increased concentrations in river water may saturate uptake. This fits with the general pattern of mass balance processes driving phosphorus uptake and regeneration dynamics in aquatic systems (Reddy et al. 1999). For $\mathrm{NH}_{4}{ }^{+}$flux, two parameters were selected in the model: $\mathrm{NH}_{4}^{+}$concentration and water temperature. These results could point towards microbial activity associated with assimilative nitrogen uptake as the driving process (Bernal et al. 2017; Webster et al. 2003). However, the negative beta coefficient associated with $\mathrm{NH}_{4}{ }^{+}$concentration suggests that regeneration increases and uptake slows with increased river nutrients, perhaps signalling N saturation or ammonification (Grimm et al. 2005; Jiao et al. 2009). Finally, DOC flux was explained by $\mathrm{NH}_{4}{ }^{+}$and DOC concentrations. In this model, the negative beta coefficient associated with DOC concentration again suggests that increased DOC leads to regeneration rather than uptake of DOC, which was demonstrated in the shift of DOC flux from uptake in July to regeneration in October in the 0-3 min exposure at U0.2 and D1.0. However, the positive beta coefficient associated with $\mathrm{NH}_{4}{ }^{+}$concentration may support DOC as a carbon source for assimilative nitrogen uptake (Webster et al. 2003; Bernal et al. 2017). Evaluating each of these models provides some indication of the relative

Table 4 Stepwise regression (forward selection) between nutrient fluxes and nutrient concentrations and water temperature. Data involved in the regression analysis contains both exposure periods. The final model summary statistics are reported for each flux (below label). Individual parameter fit summary statistics for selected models are given in grid cells $\left(\beta\right.$ is the standardized regression coefficient; $r^{2}$ is the proportion of variance for a dependent variable that's explained by an independent variable; $p$ is the significance value for each parameter reported). The blacked-out grid cells indicate that these parameters were not selected by the final model

\begin{tabular}{|c|c|c|c|c|c|}
\hline & $\begin{array}{l}\mathrm{NO}_{3}^{-} \\
\text {concen- } \\
\text { tration }\end{array}$ & $\begin{array}{l}\mathrm{NH}_{4}{ }^{+} \text {concentra- } \\
\text { tion }\end{array}$ & $\begin{array}{l}\mathrm{PO}_{4}{ }^{3-} \text { concentra- } \\
\text { tion }\end{array}$ & $\begin{array}{l}\text { DOC concentra- } \\
\text { tion }\end{array}$ & Water temperature \\
\hline $\mathrm{NO}_{3}^{-}$flux & & $\beta=0.624$ & & & \\
\hline$F_{1,10}=6.369$ & & $r^{2}=0.389$ & & & \\
\hline$p=0.030$ & & $p=0.030$ & & & \\
\hline $\mathrm{NH}_{4}^{+}$flux & & $\beta=-1.083$ & & & $\beta=0.226$ \\
\hline $\mathrm{F}_{2,9}=71.02$ & & $r^{2}=0.906$ & & & $r^{2}=0.034$ \\
\hline$p<0.001$ & & $p<0.001$ & & & $p=0.050$ \\
\hline $\mathrm{PO}_{4}{ }^{3-}$ flux & & & $\beta=-0.572$ & & \\
\hline $\mathrm{F}_{1,10}=4.859$ & & & $r^{2}=0.327$ & & \\
\hline$p=0.052$ & & & $p=0.052$ & & \\
\hline DOC flux & & $\beta=0.817$ & & $\beta=-0.548$ & \\
\hline $\mathrm{F}_{2,9}=11.12$ & & $r^{2}=0.436$ & & $r^{2}=0.278$ & \\
\hline$p=0.004$ & & $p=0.002$ & & $p=0.017$ & \\
\hline
\end{tabular}


importance of biological and physical processes which drive the dynamics of nutrients at the sediment-water interface in urban rivers affected by WWTP effluents.

\subsection{Research Limitations}

Our results provide further evidence to show that reductions in river water nutrients are paramount for improving river ecological conditions. However, there are some limitations to the flux chambers used in our research, which need to be further investigated. After water and sediments were mixed, we regarded biological processes as separate effects on nutrient fluxes after sediment settlement was visualized (i.e., after $3 \mathrm{~min}$ ). While our results and those of a previous study (Lavelle et al. 2019) do support the idea of a separation of physical versus biological activity, microbially mediated uptake/regeneration processes clearly would have been active during the initial stages of our experiments when water movement slowed and sediment particles settled. To address this issues, future experiment should include a negative control where chemicals that can stop bioactivity can be added (e.g., $\mathrm{ZnCl}_{2}$ ), thus providing a clear indication of physical versus biological processes.

Chamber experiments can distinguish between physical and biological processes, which is difficult to achieve with in-situ measurement. Additionally, chamber methods are much less expensive than tracer experiments and can be done quickly across multiple sites. However, chambers clearly cannot simulate the actual chemical and hydraulic conditions of a river. For example, although we collected water samples at different depths, there was still a lack of water advection and hyporheic flow in the flux chambers, which likely resulted in nutrient concentrations which would differ from conditions in the river.

\section{Conclusions}

This study explored concentrations and fluxes of $\mathrm{NO}_{3}{ }^{-}, \mathrm{NH}_{4}{ }^{+}, \mathrm{PO}_{4}{ }^{3-}$ and DOC at the sediment-water interface in an urban river ecosystem affected by a WWTP. Sewage effluent contributed to observed elevated concentrations and modified flux rates, resulting in significant differences across the study sites. Additionally, we observed nutrient fluxes being driven by a combination of physical and biological processes. We suggest that water movement and sediment suspension in our chamber experiments promoted the migration of nutrients between the two media under physical disturbance (e.g., time 0-3 min). Nutrients were brought into contact with sediments and absorbed and utilized by microorganisms, or biogeochemical reactions occurred due to the biological activity of sediment-surface microbes. This resulted in nutrient transformation, thus affected nutrient and DOC concentrations and flux rates in the chambers. Specifically, $\mathrm{NO}_{3}{ }^{-}$and $\mathrm{NH}_{4}{ }^{+}$fluxes relating to the $\mathrm{N}$-cycle (e.g., ammonification and nitrification) were affected by seasonal changes in water temperature and DO and presumed levels of microbial activity. For $\mathrm{PO}_{4}{ }^{3-}$ flux, we suggest that both insoluble or soluble matter in sediment affected by organic matter content and DO conditions interact with minerals and change adsorption sites and adsorption capacity of sediments, but this needs additional study to evaluate the temporospatial nature of these conditions. Additionally, competitive adsorption by anions is also a consideration for $\mathrm{PO}_{4}{ }^{3-}$ flux, linking it more directly to water $\mathrm{pH}$. The texture and particle size distribution of sediments affect the surface microbial biomass and diversity, which utilize DOC as energy and carbon source partially determining the DOC flux; this was suggested in the stepwise regression analysis of microbial uptake of DOC for nitrogen assimilation. 
Our study suggests that the increase of $\mathrm{NH}_{4}{ }^{+}$in overlying water will lead to the uptake of $\mathrm{NO}_{3}{ }^{-}$by sediments, resulting in the risk of large nitrates releases from sediments when water quality conditions change. The increase of $\mathrm{PO}_{4}{ }^{3-}$ and DOC can directly lead to their regeneration, resulting in the risk of eutrophication and organic pollution. Overall, our research on the nutrient dynamics in urban river ecosystems add to the improved understanding of factors affecting nutrient flux at the sediment-water interface and provide additional evidence to support research geared to improving ecological conditions of rivers affected by WWTP effluents by mitigating nutrient concentrations.

Supplementary Information The online version contains supplementary material available at https://doi. org/10.1007/s40710-021-00540-0.

Acknowledgements The authors thank Dr. Francis O'Shea, Dr. Kate Olde and Dr. Bruce Main for providing the laboratory and assisting in the use of experimental equipment. This research was partly funded by the Department of Geography, King's College London.

Availability of Data and Material All data are provided within the paper and in a provided Supplementary Material file.

Authors' Contributions M Zhang and M Chadwick designed the research. M Zhang led the field and lab work and wrote the first draft of the manuscript. All authors contributed editing and completion to the final draft.

Funding This research was supported in part by the Department of Geography, King's College London.

\section{Declarations}

Conflicts of Interest/Competing Interests The authors declare that they have no conflict of interest.

Open Access This article is licensed under a Creative Commons Attribution 4.0 International License, which permits use, sharing, adaptation, distribution and reproduction in any medium or format, as long as you give appropriate credit to the original author(s) and the source, provide a link to the Creative Commons licence, and indicate if changes were made. The images or other third party material in this article are included in the article's Creative Commons licence, unless indicated otherwise in a credit line to the material. If material is not included in the article's Creative Commons licence and your intended use is not permitted by statutory regulation or exceeds the permitted use, you will need to obtain permission directly from the copyright holder. To view a copy of this licence, visit http://creativecommons.org/licenses/by/4.0/.

\section{References}

Andersen CB, Lewis GP, Sargent KA (2004) Influence of wastewater-treatment effluent on concentrations and fluxes of solutes in the Bush River, South Carolina, during extreme drought conditions. Environ Geosci 11(1):28-41. https://doi.org/10.1306/eg.10200303017

Altmann D, Stief P, Amann R, de Beer D, Schramm A (2003) In situ distribution and activity of nitrifying bacteria in freshwater sediment. Environ Microbiol 5(9):798-803. https://doi.org/10.1046/j.1469-2920. 2003.00469.x

Amirbahman A, Pearce AR, Bouchard RJ, Norton SA, Steven KJ (2003) Relationship between hypolimnetic phosphorus and iron release from eleven lakes in Maine, USA. Biogeochemistry 65(3):369-386. https://doi.org/10.1023/A:1026245914721

Appling AP, Heffernan JB (2014) Nutrient limitation and physiology mediate the fine-scale (De)coupling of biogeochemical cycles. Am Nat 184(3):384-406. https://doi.org/10.1086/677282

Bedore PD, David MB, Stucki JW (2008) Mechanisms of phosphorus control in urban streams receiving sewage effluent. Water Air Soil Pollut 191(1):217-229. https://doi.org/10.1007/s11270-008-9619-x 
Belmeziti A, Cherqui F, Tourne A, Granger D, Werey C, Le Gauffre P, Chocat B (2015) Transitioning to sustainable urban water management systems: how to define expected service functions? Civ Eng Environ Syst 32(4):316-334. https://doi.org/10.1080/10286608.2015.1047355

Bernal S, Segarra A, Merbt SN, Martí E (2017) Differences in ammonium oxidizer abundance and N uptake capacity between epilithic and epipsammic biofilms in an urban stream. Freshwater Science 37(1):1322. https://doi.org/10.1086/696267

Booth DB, Roy AH, Smith B, Capps KA (2016) Global perspectives on the urban stream syndrome. Freshwater Science 35(1):412-420. https://doi.org/10.1086/684940

Braissant O, Decho AW, Dupraz C, Glunk C, Przekop KM, Visscher PT (2007) Exopolymeric substances of sulfate-reducing bacteria: interactions with calcium at alkaline $\mathrm{pH}$ and implication for formation of carbonate minerals. Geobiology 5(4):401-411. https://doi.org/10.1111/j.1472-4669.2007.00117.x

Capps KA, Bentsen CN, Ramírez A (2016) Poverty, urbanization, and environmental degradation: urban streams in the developing world. Freshwater Science 35(1):429-435. https://doi.org/10.1086/684945

Carey RO, Migliaccio KW (2009) Contribution of wastewater treatment plant effluents to nutrient dynamics in aquatic systems: a review. Environmental Management (New York) 44(2):205-217. https://doi.org/ 10.1007/s00267-009-9309-5

Chadwick MA, Dobberfuhl DR, Benke AC, Huryn AD, Suberkropp K, Thiele JE (2006) Urbanization affects stream ecosystem function by altering hydrology, chemistry, and biotic richness. Ecol Appl 16(5):1796-1807

Chen JJ, Lu SY, Liao ZY, Ai, SC, Huang MS (2012) Effect of mechanical aeration on nitrogen and microbial activity in sediment-water interface from urban lake. Applied Mechanics and Materials 260-261, 770-776. Presented at the Energy, Environment and Sustainable Development. https://doi.org/10.4028/ www.scientific.net/AMM.260-261.770

Chen YC, Tang L (2005) Study prospect on removing and transforming characteristics of nitrogen and phosphorus in sediment-water Interface. Journal-Yunnan Agricultural University 20(4):527

Cole L, Bardgett RD, Ineson P, Adamson JK (2002) Relationships between enchytraeid worms (Oligochaeta), climate change, and the release of dissolved organic carbon from blanket peat in northern England. Soil Biol Biochem 34(5):599-607. https://doi.org/10.1016/S0038-0717(01)00216-4

Correll DL, Jordan TE, Weller DE (2001) Effects of precipitation, air temperature, and land use on organic carbon discharges from rhode river watersheds. Water Air Soil Pollut 128(1):139-159. https://doi.org/ 10.1023/A:1010337623092

Dalu T, Wasserman RJ, Magoro ML, Froneman PW, Weyl OL (2019) River nutrient water and sediment measurements inform on nutrient retention, with implications for eutrophication. Sci Total Environ 684:296-302. https://doi.org/10.1016/j.scitotenv.2019.05.167

Dapeng L, Yong H, Chengxin F, Yan Y (2011) Contributions of phosphorus on sedimentary phosphorus bioavailability under sediment resuspension conditions. Chem Eng J 168(3):1049-1054. https://doi. org/10.1016/j.cej.2011.01.082

Dodds WK (2006) Eutrophication and trophic state in rivers and streams. Limnology and oceanography 51(part2):671-680. doi: https://doi.org/10.4319/1o.2006.51.1_part_2.0671

Earl SR, Valett HM, Webster JR (2006) Nitrogen saturation in stream ecosystems. Ecology 87(12):31403151. https://doi.org/10.1890/0012-9658(2006)87[3140:NSISE]2.0.CO;2

Ensign SH, Doyle MW (2006) Nutrient spiraling in streams and river networks: nutrient spiraling review. Journal of Geophysical Research: Biogeosciences 111(G4). https://doi.org/10.1029/2005JG000114

Fear JM(2003) The influence of sediment oxygen demand and denitrification on nitrogen cycling in the eutrophic Neuse River Estuary, United States. (PhD Thesis). University of North Carolina, Chapel Hill

Fellows CS, Clapcott JE, Udy JW, Bunn SE, Harch BD, Smith MJ, Davies PM (2006) Benthic metabolism as an indicator of stream ecosystem health. Hydrobiologia 572(1):71-87. https://doi.org/10.1007/ s10750-005-9001-6

Galloway JN, Townsend AR, Erisman JW, Bekunda M, Cai Z, Freney JR (2008) Transformation of the nitrogen cycle: recent trends, questions, and potential solutions. Science 320(5878):889-892. https:// doi.org/10.1126/science.1136674

Grimm NB, Sheibley RW, Crenshaw CL, Dahm CN, Roach WJ, Zeglin LH (2005) N retention and transformation in urban streams. J N Am Benthol Soc 24(3):626-642. https://doi.org/10.1899/04-027.1

Gu AZ, Tooker N (2016) Impact of advanced oxidation processes on the composition and biodegradability of soluble organic nutrients in wastewater effluents. Water Intelligence Online 15:1-70. https://doi.org/ $10.2166 / 9781780408040$

Haggard BE, Stanley EH, Storm DE (2005) Nutrient retention in a point-source-enriched stream. J N Am Benthol Soc 24(1):29-47. https://doi.org/10.1899/0887-3593(2005)024<0029:nriaps>2.0.co;2 
Heiri O, Lotter AF, Lemcke G (2001) Loss on ignition as a method for estimating organic and carbonate content in sediments: reproducibility and comparability of results. J Paleolimnol 25(1):101-110. https://doi.org/10.1023/A:1008119611481

Helton AM, Poole GC, Meyer JL, Wollheim WM, Peterson BJ, Mulholland PJ (2011) Thinking outside the channel: modeling nitrogen cycling in networked river ecosystems. Front Ecol Environ 9(4):229-238. https://doi.org/10.1890/080211

Hobbie SE, Finlay JC, Janke BD, Nidzgorski DA, Millet DB, Baker LA (2017) Contrasting nitrogen and phosphorus budgets in urban watersheds and implications for managing urban water pollution. Proc Natl Acad Sci 114(16):4177-4182. https://doi.org/10.1073/pnas.1618536114

Holmes RM, Aminot A, Kérouel R, Hooker BA, Peterson BJ (1999) A simple and precise method for measuring ammonium in marine and freshwater ecosystems. Can J Fish Aquat Sci 56(10):18011808. https://doi.org/10.1139/f99-128

Hook AM, Yeakley JA (2005) Stormflow dynamics of dissolved organic carbon and total dissolved nitrogen in a small urban watershed. Biogeochemistry 75(3):409-431. https://doi.org/10.1007/ s10533-005-1860-4

House WA, Denison FH (2000) Factors influencing the measurement of equilibrium phosphate concentrations in river sediments. Water Res 34(4):1187-1200. https://doi.org/10.1016/S0043-1354(99) 00249-3

Hu H, Xing X, Wang J, Ren H (2020) Characterization of dissolved organic matter in reclaimed wastewater supplying urban rivers with a special focus on dissolved organic nitrogen: a seasonal study. Environ Pollut 265:114959-114959. https://doi.org/10.1016/j.envpol.2020.114959

Jiao Y, Jin WB, Zhao QL, Zhang GD, Yan Y, Wan J (2009) Transformation of nitrogen and distribution of nitrogen-related bacteria in a polluted urban stream. Water Sci Technol 60(6):1597-1605. https://doi.org/10.2166/wst.2009.502

Jin X, Jiang X, Wang Q, Liu D (2008) Seasonal changes of P adsorption/desorption characteristics at the water sediment interface in Meiliang Bay, Taihu Lake, China. Acta Sci Circumst 28(1):24-30

Kalbitz K, Solinger S, Park JH, Michalzik B, Matzner E (2000) Controls on the dynamics of dissolved organic matter in soils: a review. Soil Sci 165(4):277-304

Kaushal S, Delaney-Newcomb K, Findlay S, Newcomer T, Duan S, Pennino M, Sivirichi G, Sides-Raley A, Walbridge M, Belt K (2014) Longitudinal patterns in carbon and nitrogen fluxes and stream metabolism along an urban watershed continuum. Biogeochemistry 121(1):23-44

Kirchner JW, Feng X, Neal C, Robson AJ (2004) The fine structure of water-quality dynamics: the (highfrequency) wave of the future. Hydrol Process 18(7):1353-1359. https://doi.org/10.1002/hyp.5537

Ko CH, Chang FC, Lee TM, Chen PY, Chen HH, Hsieh HL, Guan CY (2010) Impact of flood damage on pollutant removal efficiencies of a subtropical urban constructed wetland. Sci Total Environ 408(20):4328-4333. https://doi.org/10.1016/j.scitotenv.2010.06.047

Kuznetsov Y, Andreeva N (2006) Adsorption of organic anions on iron in aqueous solutions: an ellipsometric study. Russ J Electrochem 42(10):1101-1106. https://doi.org/10.1134/S102319350610017X

Lavelle AM, Bury NR, O'Shea FT, Chadwick MA (2019) Influence of urban river restoration on nitrogen dynamics at the sediment-water interface. PLoS One 14(3):e0212690. https://doi.org/10.1371/ journal.pone.0212690

Lee JY, Santamarina JC, Ruppel C (2010) Parametric study of the physical properties of hydrate-bearing sand, silt, and clay sediments: 1. Electromagnetic properties. J Geophys Res Solid Earth 115(B11). https://doi.org/10.1029/2009JB006669

Lele S, Srinivasan V, Thomas BK, Jamwal P (2018) Adapting to climate change in rapidly urbanizing river basins: insights from a multiple-concerns, multiple-stressors, and multi-level approach. Water Int 43(2):281-304. https://doi.org/10.1080/02508060.2017.1416442

Li J, Yu S, Qin S (2020) Removal capacities and environmental constrains of denitrification and Anammox processes in eutrophic riverine sediments. Water, air, \& soil pollution 231(6):274. https://doi. org/10.1007/s11270-020-04593-Z

Lin C, Wang Z, He M, Li Y, Liu R, Yang Z (2009) Phosphorus sorption and fraction characteristics in the upper, middle and low reach sediments of the Daliao river systems, China. J Hazard Mater 170(1):278-285. https://doi.org/10.1016/j.jhazmat.2009.04.102

Luo LC, Qin BQ, Zhu GW (2004) Calculation of total and resuspendable sediment volume in Lake Taihu. Oceanol Et Limnol Sin 35:491-496

Martí E, Riera JL, Sabater F (2010) Effects of wastewater treatment plants on stream nutrient dynamics under water scarcity conditions. Water Scarcity in the Mediterranean: Perspectives Under Global Change:173-195. https://doi.org/10.1007/698_2009_33 
Martí V, Jubany I, Ribas D, Benito JA, Ferrer B (2021) Improvement of phosphate adsorption kinetics onto ferric hydroxide by size reduction. Water (Basel) 13(11):1558-. doi: https://doi.org/10.3390/ w13111558

McDowell RW (2015) Relationship between sediment chemistry, equilibrium phosphorus concentrations, and phosphorus concentrations at baseflow in rivers of the New Zealand national river water quality network. Surface Water Quality 44(3):921-929. https://doi.org/10.2134/jeq2014.08.0362

Meghdadi A (2018) Characterizing the capacity of hyporheic sediments to attenuate groundwater nitrate loads by adsorption. Water Res 140:364-376. https://doi.org/10.1016/j.watres.2018.04.063

Merbt SN, Auguet JC, Blesa A, Martí E, Casamayor EO (2015) Wastewater treatment plant effluents change abundance and composition of Ammonia-oxidizing microorganisms in Mediterranean urban stream biofilms. Microb Ecol 69(1):66-74. https://doi.org/10.1007/s00248-014-0464-8

Meyer JL, Paul MJ, Taulbee WK (2005) Stream ecosystem function in urbanizing landscapes. J N Am Benthol Soc 24(3):602-612. https://doi.org/10.1899/04-021.1

Mineau MM, Wollheim WM, Buffam I, Findlay SEG, Hall RO, Hotchkiss ER, Koenig LE, McDowell WH, Parr TB (2016) Dissolved organic carbon uptake in streams: a review and assessment of reach scale measurements. Journal of geophysical research. Biogeosciences 121(8):2019-2029. https://doi.org/10. 1002/2015JG003204

Miró M, Estela JM, Cerdà V (2003) Application of flowing stream techniques to water analysis. Part I. ionic species: dissolved inorganic carbon, nutrients and related compounds. Talanta 60(5):867-886. https:// doi.org/10.1016/S0039-9140(03)00172-3

Monfared S, Dehghani DM, Snyder SA, Azizyan G, Pirzadeh B, Azhdary MM (2017) Water quality planning in Rivers: assimilative capacity and dilution flow. Bull Environ Contam Toxicol 99(5):531-541. https://doi.org/10.1007/s00128-017-2182-7

Mulholland PJ, Helton AM, Poole GC, Hall RO, Hamilton SK, Peterson BJ (2008) Stream denitrification across biomes and its response to anthropogenic nitrate loading. Nature 452(7184):202-205. https:// doi.org/10.1038/nature06686

Pant H, Reddy K (2001) Phosphorus sorption characteristics of estuarine sediments under different redox conditions. J Environ Qual 30(4):1474-1480. https://doi.org/10.2134/jeq2001.3041474x

Penn MR, Auer T, Orman EV, Korienek JJ (1995) Phosphorus diagenesis in lake sediments: investigations using fractionation techniques. Mar Freshw Res 46(1):89-99. https://doi.org/10.1071/mf9950089

Pereda O, Solagaistua L, Atristain M, de Guzmán I, Larrañaga A, von Schiller D, Elosegi A (2020) Impact of wastewater effluent pollution on stream functioning: a whole-ecosystem manipulation experiment. Environ Pollut 258:113719. https://doi.org/10.1016/j.envpol.2019.113719

Perryman SE, Rees GN, Walsh CJ, Grace MR (2011) Urban stormwater runoff drives denitrifying community composition through changes in sediment texture and carbon content. Microb Ecol 61(4):932940. https://doi.org/10.1007/s00248-011-9833-8

Pfeifer LR, Bennett EM (2011) Environmental and social predictors of phosphorus in urban streams on the island of Montréal, Québec. Urban Ecosyst 14(3):485-499. https://doi.org/10.1007/s11252-011-0160-0

Pike T, Bedford C, Davies B, Brown D (2014) A catchment Plan for the river Wandle (p. 193). London: the Wandle trust. https://www.wandletrust.org/wp-content/uploads/2014/12/Wandle_Catchment_Plan_-_ Sept_2014_-_full_document.pdf. Accessed 18 Jun 2018

Preisner M (2020) Surface water pollution by untreated municipal wastewater discharge due to a sewer failure. Environmental Processes 7(3):767-780. https://doi.org/10.1007/s40710-020-00452-5

Rabalais NN (2002) Nitrogen in aquatic ecosystems. AMBIO: A Journal of the Human Environment 31(2):102-112. https://doi.org/10.1579/0044-7447-31.2.102

Ranta E, Vidal-Abarca M, Calapez A, Feio M (2021) Urban stream assessment system (UsAs): an integrative tool to assess biodiversity, ecosystem functions and services. Ecol Indic 121:106980

Reddy KR, Kadlec RH, Flaig E, Gale PM (1999) Phosphorus retention in streams and wetlands: a review. Crit Rev Environ Sci Technol 29(1):83-146. https://doi.org/10.1080/10643389991259182

Reisinger AJ, Groffman PM, Rosi-Marshall EJ (2016) Nitrogen-cycling process rates across urban ecosystems. FEMS microbiology ecology 92(fiw198). doi: https://doi.org/10.1093/femsec/fiw198

River Wandle Catchment Plan (2014) Available at: http://wwwwandletrustorg

Rodríguez-Castillo T, Estévez E, González-Ferreras AM, Barquín J (2019) Estimating ecosystem metabolism to entire river networks. Ecosystems (New York) 22(4):892-911. https://doi.org/10.1007/ s10021-018-0311-8

Santomauro G, Baier J, Huang W, Pezold S, Bill J (2012) Formation of calcium carbonate polymorphs induced by living microalgae. Journal of Biomaterials and Nanobiotechnology 3(4):720-726. https:// doi.org/10.4236/jbnb.2012.34041 
Sessitsch A, Weilharter A, Gerzabek MH, Kirchmann H, Kandeler E (2001) Microbial population structures in soil particle size fractions of a long-term fertilizer field experiment. Appl Environ Microbiol 67(9):4215-4224. https://doi.org/10.1128/AEM.67.9.4215-4224.2001

Simon KS, Chadwick MA, Huryn AD, Valett HM (2010) Stream ecosystem response to chronic deposition of $\mathrm{N}$ and acid at the bear brook watershed, Maine. Environ Monit Assess 171(1-4):83-92

Smith B, Chadwick MA (2014) Litter decomposition in highly urbanized rivers: influence of restoration on ecosystem function. Fundamental and Applied Limnology/Archiv für Hydrobiologie 185(1):7-18

Smith L, Watzin MC, Druschel G (2011) Relating sediment phosphorus mobility to seasonal and diel redox fluctuations at the sediment-water interface in a eutrophic freshwater lake. Limnol Oceanogr 56(6):2251-2264. https://doi.org/10.4319/lo.2011.56.6.2251

Smucker NJ, Detenbeck NE (2014) Meta-analysis of lost ecosystem attributes in urban streams and the effectiveness of Out-Of-Channel management practices. Restor Ecol 22(6):741-748. https://doi.org/ $10.1111 /$ rec. 12134

Song K, Winters C, Xenopoulos MA, Marsalek J, Frost PC (2017) Phosphorus cycling in urban aquatic ecosystems: connecting biological processes and water chemistry to sediment $\mathrm{P}$ fractions in urban stormwater management ponds. Biogeochemistry 132(1):203-212. https://doi.org/10.1007/ s10533-017-0293-1

Souza AC, Pease TK, Gardner WS (2011) The direct role of enzyme hydrolysis on ammonium regeneration rates in estuarine sediments. Aquatic Microbial Ecology: International Journal 65(2):159-168. https:// doi.org/10.3354/ame01541

Wakida FT, Lerner DN (2005) Non-agricultural sources of groundwater nitrate: a review and case study. Water Res 39(1):3-16. https://doi.org/10.1016/j.watres.2004.07.026

Walsh CJ, Roy AH, Feminella JW, Cottingham PD, Groffman PM, Morgan RP (2005) The urban stream syndrome: current knowledge and the search for a cure. J N Am Benthol Soc 24(3):706-723. https:// doi.org/10.1899/04-028.1

Wang S, Jin X, Zhao H, Wu F (2009) Phosphorus release characteristics of different trophic lake sediments under simulative disturbing conditions. J Hazard Mater 161(2):1551-1559. https://doi.org/10.1016/j. jhazmat.2008.05.004

Webster JR, Mulholland PJ, Tank JL, Valett HM, Dodds WK, Peterson BJ (2003) Factors affecting ammonium uptake in streams - an inter-biome perspective. Freshw Biol 48(8):1329-1352. https://doi.org/10. 1046/j.1365-2427.2003.01094.x

Wenger SJ, Roy AH, Jackson CR, Bernhardt ES, Carter TL, Filoso S (2009) Twenty-six key research questions in urban stream ecology: an assessment of the state of the science. Freshwater Science 28(4):1080-1098. https://doi.org/10.1899/08-186.1

Worrall F, Burt T, Shedden R (2003) Long term records of riverine dissolved organic matter. Biogeochemistry 64(2):165-178. https://doi.org/10.1023/A:1024924216148

Wu J, Chen N, Hong H, Lu T, Wang L, Chen Z (2013) Direct measurement of dissolved N2 and denitrification along a subtropical river-estuary gradient, China. Mar Pollut Bull 66(1):125-134. https://doi.org/ 10.1016/j.marpolbul.2012.10.020

Wu P, Yin A, Fan M, Wu J, Yang X, Zhang H, Gao C (2018) Phosphorus dynamics influenced by anthropogenic calcium in an urban stream flowing along an increasing urbanization gradient. Landsc Urban Plan 177:1-9. https://doi.org/10.1016/j.landurbplan.2018.04.005

Xia X, Zhang S, Li S, Zhang L, Wang G, Zhang L (2018) The cycle of nitrogen in river systems: sources, transformation, and flux. Environ Sci Process Impacts 20(6):863-891. https://doi.org/10.1039/C8EM0 0042E

Yang X, Wang S, Zhou L (2012) Effect of carbon source, C/N ratio, nitrate and dissolved oxygen concentration on nitrite and ammonium production from denitrification process by pseudomonas stutzeri D6. Bioresour Technol 104:65-72. https://doi.org/10.1016/j.biortech.2011.10.026

Zhao B, Zhang Y, Dou X, Yuan H, Yang M (2015) Granular ferric hydroxide adsorbent for phosphate removal: demonstration preparation and field study. Water Sci Technol 72(12):2179-2186. https://doi. org/10.2166/wst.2015.438

Publisher's Note Springer Nature remains neutral with regard to jurisdictional claims in published maps and institutional affiliations. 